\title{
Tomaatin ympärivuotisen lyhytviljelyn tuotantokustannus ja kannattavuus
}

Timo Karhula, Pia Outa

MTT Taloustutkimus (MTTL), Luutnantintie 13, Helsinki

timo.karhula@mtt.fi,pia.outa@mtt.fi

\section{Tiivistelmä}

Tomaatin ympärivuotista tuotantoa voidaan tehostaa väli-istutuksin. Tällöin tomaattikasvusto uudistetaan siten, että vanhan kasvuston sadon loppuessa uudempi kasvusto tulee satoikään, jolloin voidaan puhua ns. lyhytviljelystä. Tavoitteena on pitää kasvihuone jatkuvasti satoa tuottavana, jolloin myös taloudellisia tuottoja ja kustannuksia syntyy koko ajan. Tavanomaisessa viljelyssä kasvuston vaihdon yhteydessä tuotantoon tulee tauko.

Tutkimuksen tavoitteena oli selvittää tomaatin lyhytviljelyn taloudellisia tekijöitä; tuotantokustannusta, tuloksen muodostumista ja kannattavuutta, kun tomaatin väli-istutuksia tehtiin viisi kappaletta vuodessa. Tutkimus perustui MTT Taloustutkimuksen puutarhatalouden tilamalleihin. Perinteisen tomaatintuotannon tilamallia muokattiin kuvaamaan lyhytviljelymenetelmää. Laskelma laadittiin $2000 \mathrm{~m}^{2}$ :n kasvihuonealalle. Satomääriä ja tuotantopanosten käyttötiedot olivat MTT Puutarhatuotannon viljelykokeesta vuosilta 2001-2002. Satotaso viidestä kasvustosta oli $66 \mathrm{~kg} / \mathrm{m}^{2}$. Viljelykokeista saatiin tuotantopanosten käyttötiedot mm. kasvinsuojelusta, energian kulutuksesta ja lannoituksesta. Laskelmassa on käytetty vuoden 2004 hintatasoa. Tomaatin ympärivuotisen lyhytviljelyn työpanoslaskelmat laati Työtehoseura.

Tomaatin lyhytviljelyssä tuotantokustannukseksi muodostui $169 € / \mathrm{m}^{2}$, joka satokiloa kohden on 2,56€. Muuttuvat kustannukset muodostivat tuotantokustannuksesta $66 \%$ ollen $112 € / \mathrm{m}^{2}$. Yrittäjäperheen palkkavaatimuksen osuus oli $13 \%\left(22 € / \mathrm{m}^{2}\right)$, poistojen $9 \%\left(15 € / \mathrm{m}^{2}\right)$, kiinteiden kustannusten $5 \%\left(8 € / \mathrm{m}^{2}\right)$ ja korkojen $7 \%\left(12 € / \mathrm{m}^{2}\right)$ tuotantokustannuksesta. Energiakustannus on yli kolmanneksen tuotantokustannuksesta (37\%).

Liikevaihto muodostuu tomaatin myyntituloista ja kasvihuonetuotannon tuesta. $2000 \mathrm{~m}^{2}: \mathrm{n}$ tilamallilla liikevaihtoa kertyi $160 € / \mathrm{m}^{2}$, joka on $2,42 €$ satokiloa kohti laskettuna. Liikevaihdosta myyntitulojen osuus oli $93 \%$ ja tuen $7 \%$.

Yrittäjän voitto tai tappio kuvaa tuotannon absoluuttista kannattavuutta, sillä tällöin liikevaihdosta on vähennetty kaikki tuotannosta aiheutuvat kustannukset. Tomaatin ympärivuotisessa lyhytviljelyssä yrittäjän tappiota syntyi $-9 € / \mathrm{m}^{2}$ eli $-0,14 €$ satokiloa kohden. Tällöin yrittäjän on tingittävä kustannuksiin huomioiduista yrittäjäperheen palkkavaatimuksesta $(11,80 € / \mathrm{h})$ ja pääoman korkovaatimuksesta (5\%). Tomaatin tuotanto lyhytviljelymenetelmällä ei ole kuitenkaan täysin kannattamatonta. Tappiosta huolimatta yrittäjäperheen palkaksi jää vielä $8,6 €$ työtuntia kohden, ja pääomalle saadaan korkoa $3,6 \%$.

Tomaatin ympärivuotisen lyhytviljelyn avulla voidaan tuottaa suuri sato ja päästä näin kannattavan tuotannon edellytyksiin kiinni. Suureen satoon liittyy kuitenkin myös suuret tappion mahdollisuudet, sillä myös tuotantokustannukset ovat korkeita. Jos esimerkiksi satoa ei saada myytyä tai sato joudutaan myymään alhaisella hinnalla, muodostuu tuotantokustannuksen ja tuottajahinnan erotus suureksi, jolloin tappion syntymistä ei voida välttää. Tomaatin ympärivuotiseen lyhytviljelyyn liittyykin monia taloudellista epävarmuutta aiheuttavia tekijöitä, mutta myös mahdollisuuksia.

Asiasanat: tomaatti, lyhytviljely, väli-istutus, ympärivuotinen tuotanto, tuotantokustannus, kannattavuus 


\section{Johdanto}

Yritystoiminnan suunnittelussa koko yrityksen ja myös yksittäisten tuotteiden kustannusrakenteen tunteminen on tärkeää. Samoin taloudellisien tekijöiden kehityksen ennakointi ja seuraaminen sekä muutoksiin reagoiminen ovat perusedellytyksiä yritystoiminnan jatkumiselle pitkällä aikavälillä. Yrityksen toiminnan suunnittelussa asetetaan tavoitteita ja kehitetään eri toimintavaihtoehtoja näiden tavoitteiden saavuttamiseksi. Suunnittelu huipentuu yleensä tietyn toimintavaihtoehdon valintaan. Kasvihuoneyrityksissä tomaatin lyhytviljely väli-istutusmenetelmällä voi olla yksi toimintavaihtoehto. Väli-istutusmenetelmässä kasvustoa vaihdetaan usein yhden pitkäaikaisen kasvuston sijaan (Richardson 1982).

Suomessa tuotetaan tomaattia vuosittain noin 35 miljoonaa kiloa 120 hehtaarin kasvihuonealalla ja 800 kasvihuoneyrityksen voimin (MMM 2005). Kotimaisen tomaatin tuotannon markkinahintainen arvo on ollut viime vuosina noin 45 miljoonaa euroa. Ympärivuotisesti tuotetun tomaatin tuotantomäärät ja pinta-alat ovat olleet viime vuosina voimakkaassa kasvussa. Tällä hetkellä ympärivuotista tuotantoa on Suomessa jo noin 20 hehtaarilla eli $17 \%$ tomaattipinta-alasta. Ympärivuotisella tuotannolla pyritään vastaamaan kuluttajien kasvaneeseen kotimaisen tomaatin kysyntään myös talviaikaan. Ympärivuotinen tuotanto luo siten terveellisiä tuoreita vihanneksia ja kasvihuoneyrittäjille toimeentulomahdollisuuksia myös talviaikaan.

Ympäri vuoden kestävässä viljelyssä tomaattikasvustoja on yleensä useampia, sillä syksyllä istutetun kasvuston sadontuottokyky heikkenee kevättä kohti. Tomaatin ympärivuotista tuotantoa voidaan tehostaa väli-istutuksin. Tällöin tomaattikasvustoa vaihdetaan usein, ja kasvusto uudistetaan siten, että vanhan kasvuston sadon loppuessa uudempi kasvusto tulee satoikään (Näkkilä 2005). Tavoitteena on pitää kasvihuone jatkuvasti satoa tuottavana, jolloin myös taloudellisia tuottoja ja kustannuksia syntyy koko ajan. Tässä tutkimuksessa oli tavoitteena selvittää tomaatin tuotannon taloudellisia tekijöitä; tuotantokustannuksia, tuloksen muodostumista ja kannattavuutta, kun tomaatin väliistutuksia suoritetaan viisi kappaletta vuodessa.

\section{Aineisto ja menetelmät}

Tutkimuksessa käytettiin MTT Taloustutkimuksen puutarhatalouden tilamalleja (Koivisto 2004). Tomaatintuotannon tilamalli muokattiin kuvaamaan MTT Puutarhatuotannon tomaatin lyhytviljelyn viljelykoetta vuosilta 2001 - 2002 (Näkkilä 2005). Viljelykokeesta saatiin aineistoa tilamalliin mm. tuotantopanosten käytöstä (taimitiheys, kasvinsuojelu, energian kulutus, lannoitus) sekä satomääristä. Vuoden aikana tehtiin viisi väli-istutusta, ja ensimmäisen laatuluokan satoa saatiin viidestä kasvustosta $66 \mathrm{~kg} / \mathrm{m}^{2}$. Tomaatin ympärivuotisen lyhytviljelyn työpanoslaskelmat laati Työtehoseura.

Tutkimusmenetelmänä oli staattinen tilamallitarkastelu. Mallintamista jouduttiin käyttämään hyväksi, koska yritystasolta tai tilastoista ei ollut riittävästi tietoa saatavilla. Tilamallit perustuvat normilukuihin ja yleisiin viljelynormeihin sekä taustaoletuksiin. Tilamalleissa joudutaan tekemään oletuksia mm. tuotanto-olosuhteista, yrityskoosta, tuotantoteknologiasta ja tuotantopanosten käytöstä, joten ne eivät kaikilta osin vastaa käytännössä toimivien puutarhayritysten reaali- ja rahaprosessia. Tilamallilaskelmat ovatkin herkkiä niissä käytettyjen oletusten suhteen. Staattisten tilamallien etuna voidaan pitää sitä, että mallien avulla voidaan tarkastella yksittäisten tuotto- tai kustannuserien, hintojen tai työpanoksen muutoksia ilman, että muut tekijät muuttuvat.

Tässä tutkimuksessa tilamallin peruslähtökohtana on $2000 \mathrm{~m}^{2}: n$ kokoinen kasvihuone. Staattinen tilamalli tuottaa oikaistun tuloslaskelman. Tuloslaskelmassa tuotoista vähennetään aluksi tuottojen aikaansaamiseksi tarvitut muuttuvat ja kiinteät kustannukset. Tuotot muodostuvat tomaatin myyntituotoista ja kasvihuonetuotannolle maksettavista tuista. Tuloslaskelmassa muuttuvat kustannukset sisältävät tarvike- ja yleiskulut. Kiinteät kustannukset sisältävät palkatun työvoiman palkka-, kunnossapito- ja vakuutuskulut. Muuttuvien ja kiinteiden kustannusten vähennyksen jälkeen liikevaihdosta saadaan käyttökate. Kun käyttökatteesta vähennetään edelleen poistot, saadaan liiketulos. Käyttökate ja liiketulos sisältävät yrittäjäperheen palkkavaatimuksen. Vähentämällä liiketuloksesta yrittäjäperheen palkkavaatimus ja pääoman korkovaatimus, saadaan yrittäjänvoitto (taulukko 1). Tutkimuksessa yrittäjäperheen palkkavaatimuksena käytettiin $11,80 € / \mathrm{h}$ ja pääoman korkovaatimuksena $5 \%$. Vastaavia arvoja on käytetty maatalouden kannattavuustutkimuksessa tilivuonna 2003 (MTT 2005). 


\section{Tulokset ja tulosten tarkastelu}

Tomaatin lyhytviljelyssä tuotantokustannukseksi muodostui $2000 \mathrm{~m}^{2}: \mathrm{n}$ kasvihuonetilamallilla $169 € / \mathrm{m}^{2}$, joka on satokiloa kohden laskettuna 2,56€. Muuttuvat kustannukset muodostivat tuotantokustannuksesta $66 \%$ ollen $112 € / \mathrm{m}^{2}$. Yrittäjäperheen palkkavaatimuksen osuus oli $13 \%\left(22 € / \mathrm{m}^{2}\right)$, poistojen $9 \%\left(15 € / \mathrm{m}^{2}\right)$, kiinteiden kustannusten $5 \%\left(8 € / \mathrm{m}^{2}\right)$ ja korkojen $7 \%\left(12 € / \mathrm{m}^{2}\right)$ (taulukko 1$)$. Kustannuslajeittain tarkasteltuna energian osuus (sähkö ja lämmitys) tuotantokustannuksesta on suuri, $37 \%$ eli $63 € / \mathrm{m}^{2}$ (kuva 1). Talviaikaan tomaattikasvustoa valotetaan reilusti, joten sähköenergian kustannus on suuri, $51 € / \mathrm{m}^{2}$. Lisäksi tarvike- ja yleiskustannukset muodostavat tuotantokustannuksesta 13 $\%\left(21 € / \mathrm{m}^{2}\right)$, omaisuudesta aiheutuvat kustannukset $20 \%\left(33 € / \mathrm{m}^{2}\right)$ ja työkustannus $15 \%\left(26 € / \mathrm{m}^{2}\right)$.

Tomaatintuotannon liikevaihto muodostuu tomaatin myyntituloista sekä kasvihuonetuotannon tuesta. $2000 \mathrm{~m}^{2}:$ n tilamallilla tomaatin liikevaihto oli $160 € / \mathrm{m}^{2}$, eli $2,42 € / \mathrm{kg}$. Liikevaihdosta $93 \%$ muodostuu tomaatin myyntituloista ja $7 \%$ tuesta.

Käyttökatteeksi tilamallilla muodostuu $39 € / \mathrm{m}^{2}$, joka on $0,60 €$ satokiloa kohden. Taloudellisen tuloksen muodostumisessa käyttökate kattaa vain osan yrittäjäperheen palkkavaatimuksesta ja pääomakuluista. Näin ollen yrittäjäperheen työpanoksen tarve tai pääomarakenne on liian raskas yritystoiminnan kannettavaksi (kuva 2).

Liiketulos kuvaa sitä taloudellista korvausta, joka jää yrittäjäperheen työlle ja pääomalle. Tuloskäsitteenä liiketuloksen avulla ei voida arvioida tuotannon kannattavuutta, koska se on korvausta kahdelle eri panostekijälle. Tomaatin lyhytviljelyssä liiketulos on $25 € / \mathrm{m}^{2}$ ja siten satokiloa kohden $0,37 €$. Positiivisen liiketuloksen yrittäjä voi käyttää esim. kulutukseen oman pääoman määrän muuttumatta. Toisena vaihtoehtona on kasvattaa oman pääoman määrää. Positiivisen liiketuloksen avulla yritykseen muodostuu omaa pääomaa, mikä helpottaa yrityksen kasvua ja luo myös vakavaraisuuden perustan.

Yrittäjän voitto tai tappio kuvaa, kuinka paljon yrityksen omistajille jää voittoa, kun liiketuloksesta vähennetään yrittäjien palkkavaatimus ja pääoman korkovaatimus. Yrittäjän voitto kuvaa yrityksen absoluuttista kannattavuutta, koska kaikki tuotantokustannukset on vähennetty liikevaihdosta. Tomaatin tuotannossa syntyy kuitenkin yrittäjän tappiota $-9 € / \mathrm{m}^{2}$ eli $-0,14 €$ satokiloa kohden (kuva 2). Tällöin joudutaan tinkimään ennalta asetetuista yrittäjäperheen palkkavaatimuksesta $(11,80 € / \mathrm{h})$ ja pääoman korkovaatimuksesta (5\%). Tomaatin ympärivuotinen tuotanto ei ole täysin kannattamatonta, vaikka yrittäjäntappiota syntyy. Yrittäjäperheen palkaksi jää työtuntia kohden noin $8,6 €$ ja pääomalle korkoa noin 3,6 \%. Tuotantoa voidaan tällöin pitää kohtuullisesti kannattavana.

\section{Johtopäätökset}

Tomaatin ympärivuotisessa lyhytviljelyssä myyntitulot muodostavat liikevaihdosta $93 \%$, joten tuotanto on markkinahintalähtöistä. Kannattavuuskirjanpitotiloilla myyntitulojen osuus kokonaistuotoista on ollut keskimäärin $75 \%$. Kannattavuuskirjanpitoaineistoon verrattuna tomaatin lyhytviljelyssä saavutetaan noin kolminkertainen liikevaihto, mutta samalla myös tuotantokustannukset ovat kolminkertaiset, sillä tomaatin lyhytviljelyssä esimerkiksi satotaso on korkeampi kuin kirjanpitoaineiston yrityksillä.

Tomaatin myyntituloihin vaikuttaa suoraan tomaatin tuottajahinta. Tuottajahinta voi kuitenkin vaihdella paljon jopa päivä- ja viikkotasolla, mistä aiheutuu yritystoimintaan taloudellista epävarmuutta. Taloudellinen epävarmuus korostuu, jos hinnat vaihtelevat voimakkaasti ja ennakoimattomasti lyhyellä aikavälillä, mitä on ollut havaittavissa Suomen tomaattimarkkinoilla. Pitkällä aikavälillä yritystoimintaan hintojen vaihtelusta aiheutuvaa epävarmuutta voidaan pyrkiä minimoimaan esimerkiksi laajentamalla tuotevalikoimaa tai laatimalla hintasopimuksia tuotteiden ostajien kanssa.

Tomaatin ympärivuotisesta lyhytviljelystä syntyy tuloja tauotta, mutta samalla syntyy myös kustannuksia. Tomaatin tuottajahinnan vaihtelun lisäksi energiakustannuksen kasvaminen aiheuttaa taloudellista epävarmuutta yritystoiminnan harjoittamiseen. Ympärivuorisessa tuotannossa energiakustannus on erittäin merkittävä kustannuserä, sillä sen osuus tuotantokustannuksista on 37 \%. Yksistään sähkön hinnan muutokset vaikuttavat merkittävästi taloudellisen tuloksen muodostumiseen ja tuotannon kannattavuuteen. Viime vuosina energian hinnat ovat Suomessa nousseet yleistä kustannustasoa nopeammin, mikä heikentää suoraan tomaatin ympärivuotisen lyhytviljelyn taloutta. 
Tomaatin lyhytviljelyssä muuttuvilla kustannuksilla on suuri osuus tuotantokustannuksen rakenteessa verrattuna kiinteisiin kustannuksiin. Tältä osin tomaatin lyhytviljelyssä tuotantokustannusrakenne on kirjanpitoaineiston tomaattiviljelmien kanssa samankaltainen. Kiinteät kustannukset rasittavat yritystoimintaa tuotannon asteesta riippumatta, joten niiden suhteellisen alhainen osuus tuotantokustannuksesta on yritystoiminnan kannalta hyvä asia. Kiinteät kustannukset rasittavat yritystoimintaa kuitenkin myös sen keskeytyessä tai loppuessa. Muuttuvat kustannukset ovat kertaluonteisempia, sillä ne rasittavat yritystoimintaa tuotantovolyymien mukaisesti.

Yrittäjänvoitto kuvaa yritystoiminnan absoluuttista kannattavuutta, sillä siinä kaikki kustannukset on vähennetty tuotoista. Jos tuotot ovat kustannuksia suuremmat, on yritystoiminta kannattavaa eli ennalta asetetut taloudelliset tavoitteet saavutetaan tai ne jopa ylitetään. Taloudellisten tavoitteiden tai vaateiden taso riippuu kuitenkin mm. yrittäjän preferensseistä eli siitä, minkälaiseen korvaukseen hän tyytyy omalle työlleen ja tuotantoon sidotulle pääomalle. Tomaatin lyhytviljelyssä kannattavuuskeroin on 0,73 . Tällöin alkuperäisistä laskennallisista kannattavuustavoitteista on tingittävä noin $30 \%$. Saavutettuja taloudellisia korvauksia työ- ja pääomapanokselle voidaan pitää kuitenkin suhteellisen kohtuullisina.

Tomaatin lyhytviljelyn avulla voidaan tuottaa suuri sato ja päästä näin kannattavan tuotannon edellytyksiin kiinni. Suureen satoon liittyy kuitenkin myös suuret tappion mahdollisuudet, sillä myös tuotantokustannukset ovat korkeita. Jos esimerkiksi satoa ei saada myytyä tai sato joudutaan myymään alhaisella hinnalla, muodostuu tuotantokustannuksen ja tuottajahinnan erotus suureksi, jolloin tappion syntymistä ei voida välttää. Tomaatin lyhytviljelyyn liittyykin monia taloudellista epävarmuutta aiheuttavia tekijöitä, mutta samalla myös mahdollisuuksia.

\section{Kirjallisuus}

Koivisto, A. 2004. Puutarhayritysten tuotantokustannusten seurantamallit. MTT:n selvityksiä 71.64 s. http://www.mtt.fi/mtts/pdf/mtts71.pd

MMM 2005. Puutarhayritysrekisteri 2004. Maa- ja metsätalousministeriön tietopalvelukeskus. Helsinki. 128 s.

MTT 2005. Maa- ja puutarhatalouden kannattavuustutkimus. Kirjanpitotilojen tulokset tilivuodelta 2003. http://www.mtt.fi/tutkimus/talous/kirjanpitotilat/2003/2003.html

Näkkilä, J. 2005. Tomaatin lyhytviljely. In: Toim. Juha Näkkilä et al.. Kasvihuonevihannesten yhteyttämisen tehostaminen ympärivuotisessa tuotannossa : loppuraportti. p. 18-20.

Richardson, F. 1982. Interplanting cuts cost for tomatoes. Grower 98: (25) p. 15-17

Taulukko 1. Tuloslaskelma ja tomaatin lyhytviljelytuotannon taloudellinen tulos, kun väli-istutuksia tehtiin viisi kappaletta vuodessa.

\begin{tabular}{lccc}
\hline & $€ / \mathrm{m}^{2}$ & $€ / \mathrm{kg}$ & $\begin{array}{c}\text { Osuus tuotanto- } \\
\text { kustannuksesta }\end{array}$ \\
\hline Myyntituotot & 148 & 2.25 & \\
$\quad+$ Tuet & 11 & 0.17 & \\
Liikevaihto & 160 & 2.42 & \\
- Muuttuvat kustannukset & 112 & 1.71 & $66 \%$ \\
- Kiinteät kustannukset & 8 & 0.12 & $5 \%$ \\
Käyttökate & 39 & 0.60 & \\
- Poistot & 15 & 0.23 & $9 \%$ \\
Liiketulos & 25 & 0.37 & \\
- Yrittäjäperheen palkkavaatimus & 22 & 0.33 & $7 \%$ \\
- Pääoman korkovaatimus & 12 & 0.18 & \\
Yrittäjänvoitto /-tappio & -9 & -0.14 & \\
\hline
\end{tabular}




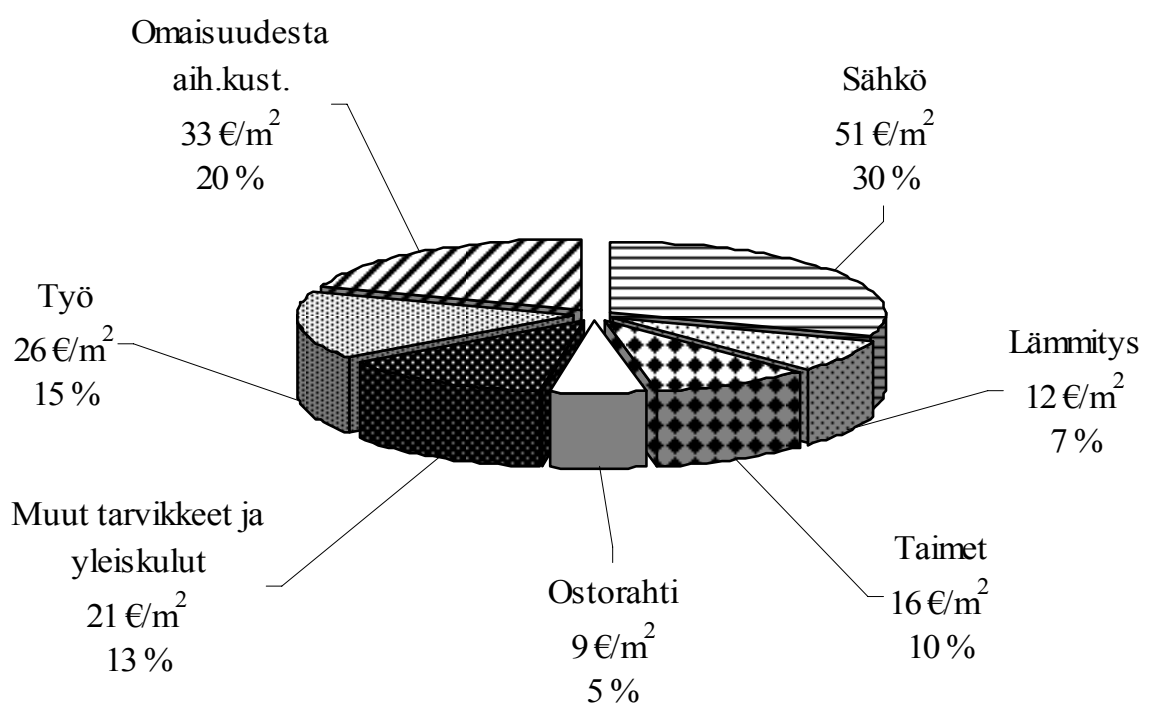

Kuva 1. Tuotantokustannus $\left(€ / \mathrm{m}^{2}\right)$ ja sen jakauma (\%) kustannuslajeittain.

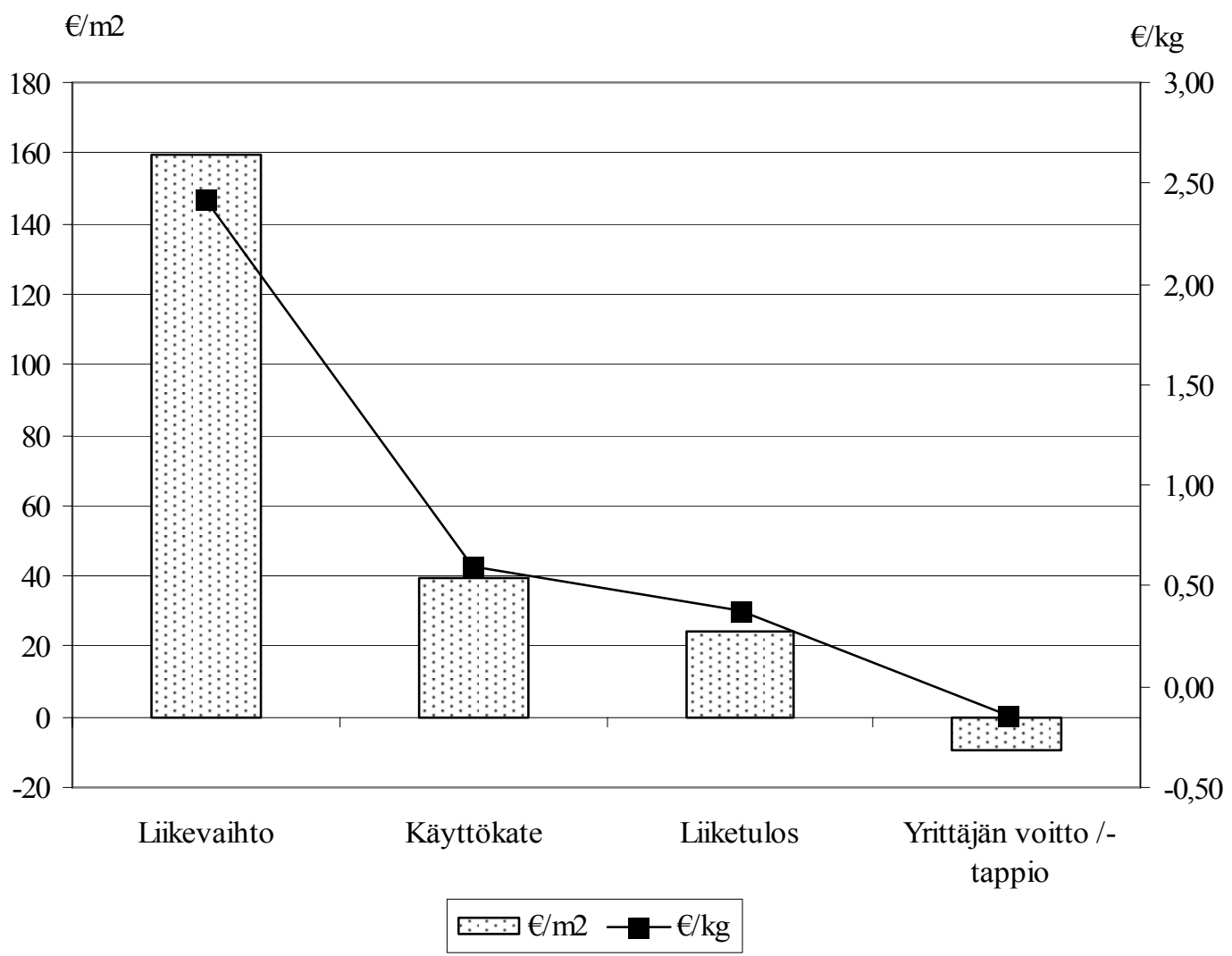

Kuva. 2. Taloudellisen tuloksen muodostuminen tilamallissa $\left(€ / \mathrm{m}^{2}\right)$ ja kiloa kohti $(€ / \mathrm{kg})$ 